\title{
Silicone oil keratopathy: indications for keratoplasty
}

\author{
W H BEEKHUIS, G VAN RIJ, AND R ŽIVOJNOVIĆ \\ From the Rotterdam Eye Hospital, Cornea and Retina Services, Erasmus University, Rotterdam, \\ The Netherlands
}

SUMMARY A penetrating corneal graft was performed in 12 patients for corneal opacification induced by silicone oil. The patients were all aphakic. They had had vitrectomy and silicone oil injection for complicated retinal detachment, often with periretinal proliferation. The average follow-up time was 13.7 months, during which four out of 11 grafts failed (one case was lost to follow-up). One patient developed severe calcific band keratopathy, and three grafts failed from endothelial decompensation. Changes induced by silicone oil include band keratopathy, thinning, and endothelial damage. The indications for keratoplasty for these corneal changes are discussed.

Silicone oil or polydimethylsiloxane fluid has been used in retinal surgery since Cibis et al. ${ }^{\prime}$ introduced this compound in 1962. Cibis et al. did not find corneal changes after injection of $0 \cdot 1 \mathrm{ml}$ of silicone oil in the anterior chamber of the rabbit. In a clinical study of 33 patients treated with intravitreal silicone oil they noticed a central endothelial haze in two aphakic eyes where the silicone oil was in contact with the cornea. This report was followed by both animal studies ${ }^{2-7}$ and clinical studies ${ }^{8-17}$ describing the effects of silicone oil in contact with the endothelium. In the animal studies either no abnormalities, ${ }^{2}$ endothelial opacification, ${ }^{3}$ or vascularisation ${ }^{5}$ of the cornea are mentioned. In patients treated with silicone oil band-shaped keratopathy, silicone granules in the corneal stroma, progressive vascularisation, and corneal decompensation or thinning were found. ${ }^{9-18}$

Corneal changes typically occur in aphakic patients when silicone oil is in permanent contact with the endothelium. In aphakic eyes without any contact of oil with the endothelium no permanent changes are reported. Occasionally emulsified oil can be seen in the superior chamber angle, occupying up to the upper third of the chamber.

Here we report on 12 patients who during 1982 underwent a penetrating corneal graft for severe corneal changes following silicone oil injection. The eyes were aphakic, and silicone oil was present in the anterior chamber and in contact with the cornea. Penetrating keratoplasty for these corneal changes has not previously been reported.

Correspondence to W H Bcekhuis, MD, Rotterdam Eye Hospital, Schiedamse Vest 180, 3011 BH Rotterdam, The Netherlands.

\section{Patients and methods}

During the year 198212 patients underwent a penetrating keratoplasty in the Rotterdam Eye Hospital for silicone oil induced corneal changes. In three patients this was a second graft. The first graft in these cases, performed during the initial reconstruction of the eye when the silicone oil was injected, became cloudy. In Table 1 the basic data for each patient are shown. The visual acuity of the affected eye before the first treatment was started and the visual acuity of the fellow eye are listed, as well as the diagnosis at the first presentation in our clinic. Most patients underwent one or more surgical interventions to treat the retinal detachment of the affected eye before silicone oil was used to support the retina. These interventions are listed in a concise form in Table 1. The visual fields of all patients except for patients 10 and 11 , who could not fixate well enough, were assessed with the Goldmann perimeter before and after surgery.

\section{OPERATIVE TECHNIQUE}

The patients were treated with intraocular injection of silicone oil ${ }^{19}$ (polydimethylsiloxane fluid) of viscosity $1000 \mathrm{cS}$, specific gravity 0.972 , refractive index $1 \cdot 4035$, molecular weight 30000 daltons (chain length 406 units, see Fig. 1). The keratoplasty procedure was started by baring the sclera at 10 o'clock over the pars plana. A Flieringa ring was secured to the sclera. A $6 \mathrm{~mm}$ to $8 \mathrm{~mm}$ button was trephined from the centre of the cornea, Descemet's membrane being cut with a razor blade knife or Vannas scissors. The open sky with an appropriate oil 
Table 1 Pre-and postkeratoplasty data for the 12 patients under study. For each patient the sex and age as well as the visual from the first silicone oil injection to the time of grafting are given.

\begin{tabular}{|c|c|c|c|c|c|c|c|}
\hline Case & $\begin{array}{l}\text { Sex, } \\
\text { age }\end{array}$ & $V A$ & $\begin{array}{l}V A \\
\text { other }\end{array}$ & $\begin{array}{l}\text { Diagnosis at } \\
\text { presentation }\end{array}$ & $\begin{array}{l}\text { No. detachment oper. } \\
\text { before sil. inject. }\end{array}$ & $\begin{array}{l}\text { Months } \\
\text { to graft }\end{array}$ & $\begin{array}{l}\text { Cornea at } \\
\text { grafting }\end{array}$ \\
\hline 1 & M, 51 & LP & $1 \cdot 0$ & $\begin{array}{l}\text { IOFB, cataract, retinal } \\
\text { detachment }\end{array}$ & $\begin{array}{l}\text { 3, incl. vitrectomy, } \\
\text { lensectomy }\end{array}$ & 7 & Oedema, PCL \\
\hline 2 & $\mathbf{M}, 33$ & LP & NLP & $\begin{array}{l}\text { Myopia gravior, giant } \\
\text { tear, MPP }\end{array}$ & $\begin{array}{l}\text { Primary oil, lensectomy, } \\
\text { vitrectomy, membr. } \\
\text { peeling }\end{array}$ & 11 & $\begin{array}{l}\text { Bullous oedema } \\
\text { PCL }\end{array}$ \\
\hline 3 & F, 25 & NLP & NLP & $\begin{array}{l}\text { Windshield perf. BE } \\
\text { first seen in our clinic } \\
9 \text { mo after accident, MPP }\end{array}$ & $\begin{array}{l}\text { 1, incl. open sky } \\
\text { vitrectomy and kerato- } \\
\text { plasty }\end{array}$ & 18 & Band kp, PCL \\
\hline 4 & M, 67 & $0 \cdot 1$ & NLP & $\begin{array}{l}\text { Motorcycle accident } \\
\text { perf. BE, aniridia, MPP }\end{array}$ & $\begin{array}{l}2 \text {, incl. vitrectomy } \\
\text { membr. peeling }\end{array}$ & 46 & $\begin{array}{l}\text { Vascularisation } \\
\text { ocdema, PCL }\end{array}$ \\
\hline 5 & $\mathrm{M}, 41$ & $1 / 60$ & $1 \cdot 0$ & $\begin{array}{l}\text { Contusion, cataract, } \\
\text { ECCE + IOL, detachment } \\
\text { MPP. }\end{array}$ & $\begin{array}{l}\text { 1, incl. buckling, } \\
\mathrm{SF}_{6} \text { injection, laser }\end{array}$ & 37 & Oedema, PCL \\
\hline 6 & M, 32 & LP & NLP & $\begin{array}{l}\text { Explosion, perf. BE } \\
\text { first seen } 1.5 \mathrm{yr} \\
\text { after accident }\end{array}$ & $\begin{array}{l}\text { Primary oil, open sky } \\
\text { reconstruction, kerato- } \\
\text { plasty }\end{array}$ & 6 & Oedema, PCL \\
\hline 7 & M, 49 & LP & NLP & $\begin{array}{l}\text { BE perforated } 18 \text { yr } \\
\text { earlicr (explosion) }\end{array}$ & $\begin{array}{l}\text { Primary oil, vitrectomy } \\
\text { membr. peeling }\end{array}$ & 4 & Ocdema, PCL \\
\hline 8 & $M, 61$ & $1 / 60$ & 0.7 & $\begin{array}{l}\text { Myopia gravis, retinal } \\
\text { detachment, MPP }\end{array}$ & $\begin{array}{l}\text { 1, incl. buckling } \\
\text { 1st keratoplasty } 22 \text { mo } \\
\text { after ICCE, clear } 12 \text { mo }\end{array}$ & 18 & $\begin{array}{l}\text { Vascularisation } \\
\text { oedema, PCL }\end{array}$ \\
\hline 9 & M, 25 & LP & $1 \cdot 0$ & Explosion, IOFB & $\begin{array}{l}\text { 1, incl. vitrectomy, } \\
\text { lensectomy }\end{array}$ & 34 & Band kp oedema \\
\hline 10 & M, 46 & LP & NLP & $\begin{array}{l}\text { Hered. macular } \\
\text { coloboma, retinal } \\
\text { detachment, MPP }\end{array}$ & $\begin{array}{l}\text { 1, incl. membr. pecling } \\
\text { cataract extraction }\end{array}$ & 22 & Oedema, PCL \\
\hline 11 & M, 72 & $0.5 / 50$ & 0.4 & $\begin{array}{l}\text { ICCE + IOL, } \\
\text { detachment, MPP }\end{array}$ & 1 , incl. buckling & 10 & $\begin{array}{l}\text { Bullous kp } \\
\text { PCL }\end{array}$ \\
\hline 12 & $F, 66$ & $1 / 300$ & LP & $\begin{array}{l}\text { ICCE, detachment BE, } \\
\text { MPP BE }\end{array}$ & $\begin{array}{l}\text { 4, incl. buckling, } \\
\text { vitrectomy, membr. } \\
\text { peeling }\end{array}$ & 22 & Bullous kp \\
\hline
\end{tabular}

$\mathrm{BE}=$ both eyes. $\mathrm{VA}=$ visual acuity. $\mathrm{LP}=$ light perception. $\mathrm{NLP}=$ no light perception. IOFB=intraocular foreign body.

$\mathrm{IOL}=$ intraocular lens. Visual acuity of $1 / 60=$ finger counting at 1 metre; $1 / 300=$ hand movements at 1 metre. $k p=K e r a t o p a t h y$.

meniscus allowed the surgeon an overview of the posterior segment that had been partially hidden by the corneal opacities. By that time the decision was made whether to remove the oil from the eye or to leave the oil in the eye. In case 5 a temporary $6.5 \mathrm{~mm}$ Landers keratoprosthesis ${ }^{20}$ was fixed in the $6.0 \mathrm{~mm}$ trephine opening to allow additional closed vitrec-

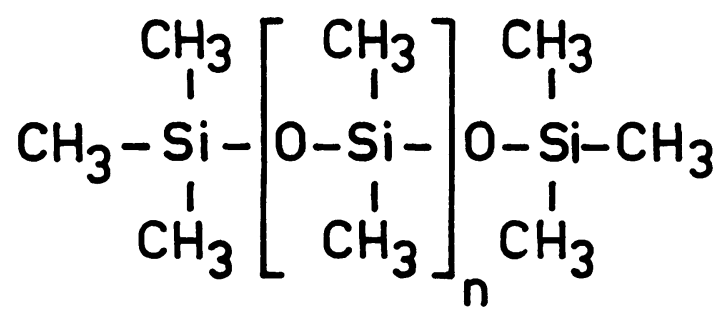

\section{$n=404$}

Fig. 1 Structural formula of silicone fluid (Polydimethylsiloxane, viscosity $1000 \mathrm{cS}$ ). tomy and membrane peeling to be performed. When silicone oil was to be removed, it was gently irrigated out of the open eye with balanced salt solution. When the oil had to remain in the eye because of an unstable retinal situation, the slight loss of oil during the keratoplasty was restored by oil injection through the bared scleral area at the 10 o'clock position over the pars plana. No attempt was made to separate the intraocular oil from the cornea. None of the patients had sufficient anterior chamber to be able to do so. Excised corneal buttons were cut in half and fixed in formaldehyde and glutaraldehyde for histopathological examination.

\section{Results}

The visual acuity before and after the keratoplasty, the duration of graft clarity, and complications are listed in Table 1 . We were able to assess visual fields in most patients (Fig. 2). The follow-up of these 12 patients ranged from 10 to 19 months (mean 13.7 months, $\mathrm{SD} \pm 4 \cdot 3$ ). 
acuity of the affected and the contralateral eye are listed. A short history is included in the table. The number of months elapsed

\begin{tabular}{|c|c|c|c|c|c|}
\hline $\begin{array}{l}V A \\
\text { before }\end{array}$ & $\begin{array}{l}V A \\
\text { after }\end{array}$ & $\begin{array}{l}\text { Follow- } \\
\text { up time } \\
\text { (months) }\end{array}$ & $\begin{array}{l}\text { Oil } \\
\text { removed } \\
\text { at keratoplasty }\end{array}$ & $\begin{array}{l}\text { Months } \\
\text { clear } \\
\text { after keratoplasty }\end{array}$ & $\begin{array}{l}\text { Complications and } \\
\text { comments }\end{array}$ \\
\hline $4 / 60$ & $0 \cdot 1$ & 19 & Yes & 19 & $\begin{array}{l}2 \text { months following graft elevated } \\
\text { IOP. Timolol regulated }\end{array}$ \\
\hline $0 \cdot 5 / 60$ & $5 / 300$ & 18 & - & 18 & $\begin{array}{l}\text { Delayed epithelialisation. } \\
\text { Elevated IOP. Timolol regulated }\end{array}$ \\
\hline LP & LP & 17 & - & 17 & Slight band kp in the graft \\
\hline $1 / 300$ & $2 / 300$ & 7 & Yes & 7 & $\begin{array}{l}\text { After } 7 \text { months lost to follow-up } \\
\text { Had carcinoma of the bladder }\end{array}$ \\
\hline $1 / 60$ & $1 / 60$ & 6 & - & 2 & Abstained, see text \\
\hline $1 / 300$ & $2 / 300$ & 13 & - & 13 & $\begin{array}{l}\text { After corneal graft twice membr. } \\
\text { peeling }\end{array}$ \\
\hline LP & $1 / 300$ & 12 & - & $1 / 2(3)$ & $\begin{array}{l}\text { Regraft after } 3 \text { weeks, see text: } \\
\text { second graft clear for three months }\end{array}$ \\
\hline $1 / 300$ & $4 / 300$ & 13 & - & 13 & $\begin{array}{l}\text { Loose suture tightened, } 5 \text { months } \\
\text { after keratoplasty }\end{array}$ \\
\hline $1 / 300$ & $0.5 / 60$ & 12 & - & 12 & $\begin{array}{l}\text { Slight back up, beginning after } \\
2 \text { months }\end{array}$ \\
\hline LP & $1 / 300$ & 10 & Yes & 10 & Clear \\
\hline $0 \cdot 5 / 60$ & $1 / 60$ & 18 & - & 11 & $\begin{array}{l}\text { Early band } \mathrm{kp} \text { in graft, } \\
\text { PCL, normal thickness }\end{array}$ \\
\hline $1 / 300$ & $2 / 60$ & 6 & - & 6 & $\begin{array}{l}\text { Regrafted after } 6 \text { months, } \\
\text { band kp and oedema }\end{array}$ \\
\hline
\end{tabular}

$\overline{\mathrm{ICCE}}=$ intracapsular cataract extraction $(\mathrm{ECCE}=$ extracapsular $) . \mathrm{PCL}=$ posterior collagenous layer. $\mathrm{MPP}=$ massive periretinal proliferation.

In three patients a slight band-shaped keratopathy developed in the graft (see Table 1, patients 3,9, and 12) after 2 to 6 months. In a fourth patient (No. 11) a more severe band keratopathy caused a loss of transparency of the graft after 11 months. Three out of 12 grafts failed within the observation period. In two cases a regraft was performed: No. 7 after three weeks (see below) and No. 12 after six months. Case 5 had promising results from the detachment surgery, and the visual field after keratoplasty was excellent (Fig. 2). But a recurrence of periretinal fibrosis set in, and the graft became oedematous two months after grafting. The bad prognosis for retinal repair and the good visual acuity in the other eye made us abstain from further treatment. Two grafts showed delayed epithelialisation. A bandage lens overcame this problem in one case. An absolute lack of epithelial growth in patient 7 , who lived abroad and could not be checked every week or so, made us perform a regraft after three weeks with a fresh donor button with viable epithelium on it.

In summary, seven out of 11 (case 4 was lost to follow-up after seven months) grafts maintained useful transparency throughout the observation period. Wound healing was not delayed or otherwise abnormal. Histology of excised keratoplasty buttons did not show any inclusions of silicone into the tissue. No homograft reactions were noted in these patients after keratoplasty.

\section{Discussion}

Permanent contact of silicone oil with the cornea results in corneal changes of various degrees of severity. A small bubble of silicone oil mobile in the anterior chamber of a phakic eye will not result in any changes of the cornea (Fig. 3, 1-6). Although emulsified oil is sometimes seen superiorly in the angle, pressure rises were not a major problem in our patients (see Table 1, complications).

Aphakic eyes that underwent complete vitrectomy with open communication between anterior and posterior segment, often with distorted or absent pupillary diaphragm, allow silicone oil to bulge 

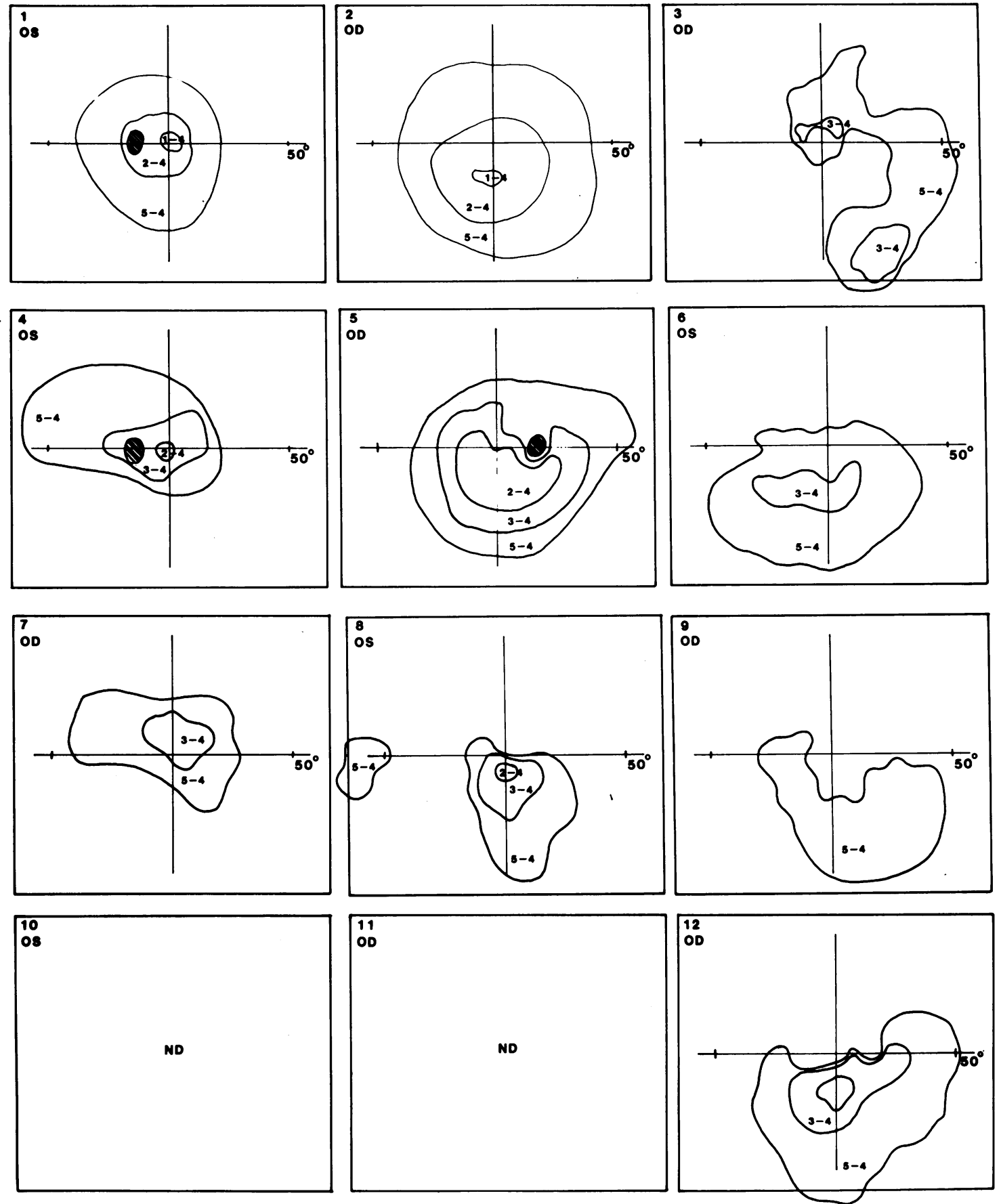

Fig. 2 Visual field of 10 of the 12 patients, Goldmann perimetry after keratoplasty.

forward and establish contact, either permanent or intermittent, with the endothelium (Fig. 3, 7 and 8). As the oil is lighter than the aqueous, changes in posture could change the position of the oil bubble within the eye. A silicone oil bubble in contact with the cornea at the slit lamp could very well float up a 


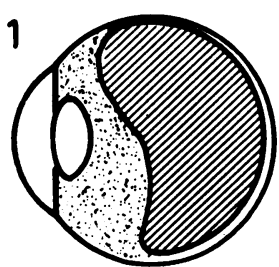

Phakic

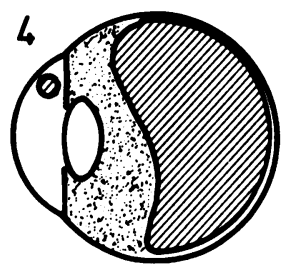

Phakic

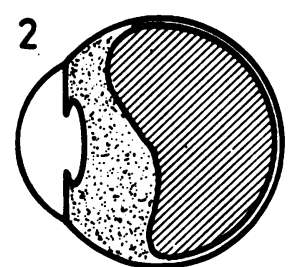

EC Aphakic

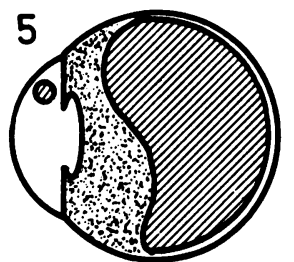

EC Aphakic

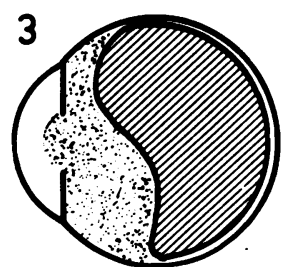

IC Aphakic little and away from the cornea in a patient lying face down. Constable et al. ${ }^{21}$ have suggested that higher viscosity silicone oil $(12500 \mathrm{cS})$ forms an artificial vitreous face in aphakics and has less tendency to enter the anterior chamber. Whether the higher viscosity would have the same advantage in patients with large distorted pupils or aniridia remains unanswered.

\section{BAND KERATOPATHY}

In some patients with a large silicone oil bubble in the anterior chamber a calcific band keratopathy developed (Fig. 4). The calcium salt deposits in Bowman's layer and superficial stroma ${ }^{22}$ can be explained by a lower metabolic rate in the cornea, ${ }^{23}$ especially in the superficial layers. Less metabolic end products like lactic acid are produced, while the loss of carbon dioxide by evaporation remains unchanged. This results in an increase in $\mathrm{pH}$ in the superficial corneal layers, and precipitation of calcium salts occurs. The silicone oil blocks the transport of nutrients from the aqueous into the cornea. ${ }^{7}$ The aqueous turnover rate might be reduced. We have not made a direct measurement of aqueous turnover rate in these patients. However, we have interpreted the combined finding of a high resistance of outflow (by tonography) and a normal intraocular pressure as a support of our theory of a decreased aqueous turnover rate.

Band-shaped keratopathy alone should not be treated by keratoplasty but by chelation with disodium EDTA $2 \%$ solution after epithelial abrasion. We have undertaken lamellar grafting for this condition (as Scott suggested in $1977^{18}$ ) in one patient, but it resulted in silicone oil in the interface and a new band keratopathy in the new graft.

\section{CORNEAL THINNING}

Thinning of the cornea over silicone oil in the anterior chamber either with or without band keratopathy is frequently seen early after oil injection. It is the result of evaporation at the corneal surface while the passive leak is being occluded by the oil bubble. This mechanism was therapeutically used in the experimental treatment of bullous keratopathy by Martola and Dohlman. ${ }^{4}$ We have performed pachometry in our patients and frequently found values below $0.45 \mathrm{~mm}$ central corneal thickness. 


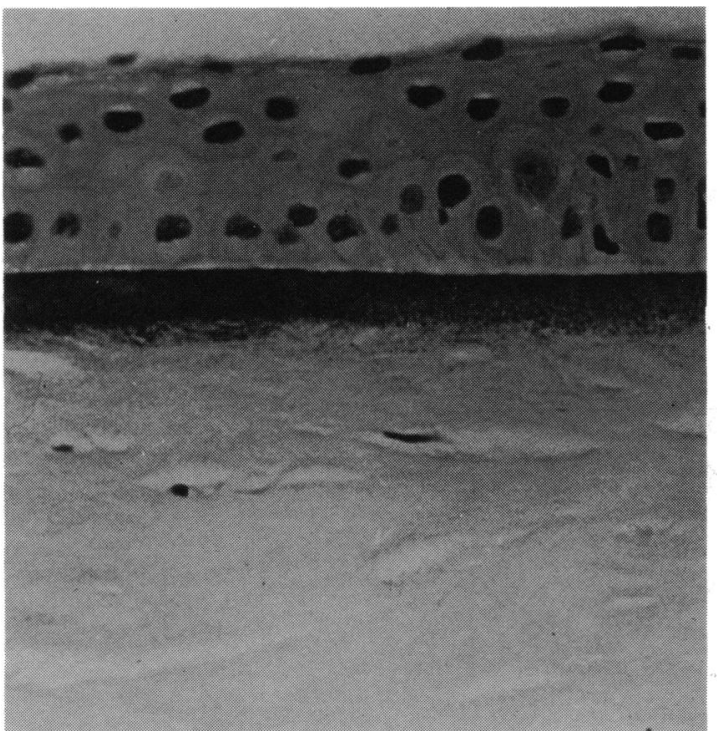

Fig. 4 Excised corneal button, showing calcific band keratopathy at the level of Bowman's and superficial stromal layers ( $H$ and $E, \times 435)$. Courtesy of W A Manschot.

\section{ENDOTHELIAL CHANGES}

Permanent contact of oil with the endothelium of longer standing (six months or longer) results in metaplasia of endothelial cells to a posterior collagenous layer. ${ }^{24}$ Biomicroscopically the endothelium is changed into a continuous grey layer. Specular microscopy would be an ideal way to monitor the slowly progressive endothelial transformation. Since the refractive indices of the corneal stroma and silicone oil are almost identical, there is no distinct specular reflex from the endothelial surface. Even when the endothelium is changed in a fibrous layer, the cornea may stay clear and of normal thickness so long as there is no aqueous leak into the stroma. In our experience removal of silicone oil from the eye in this situation led to corneal decompensation. The silicone oil prevents swelling of the cornea, but as soon as the oil is removed the malfunctioning endothelium will allow aqueous to leak into the stroma. In cases where silicone oil covers only the superior twothirds of the cornea in the erect patient fluid will leak through damaged endothelium at the lower edge of the oil bubble. Eventually, however, a number of cases end in a swollen cornea and a fibrous layer facing the anterior chamber (Fig. 5).

\section{INDICATIONS FOR KERATOPLASTY}

A penetrating corneal graft in these patients does not produce the improvement in visual acuity encountered in most other keratoplasty cases. In these patients with severe retinal problems one cannot do better

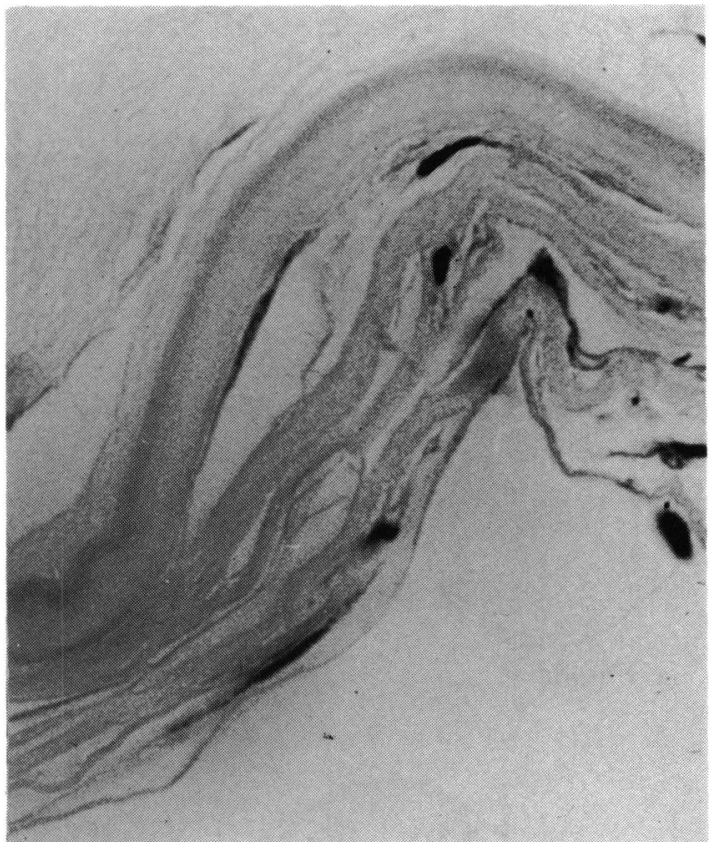

Fig. 5 Excised corneal button, showing metaplasia of the endothelium to a posterior collagenous layer. Multilayered connective tissue interposed with fibrocytes overlies Descemet's membrane (H and E, $\times 435)$. Courtesy of W A Manschot.

than at least strive for clear media, improving their visual field and clarity of vision, if not acuity of vision. Keratoplasty may also be considered when the cornea becomes too cloudy to permit funduscopy to monitor the retinal attachment or periretinal proliferative processes. To abstain from performing a graft in these patients when the cornea has become oedematous and opacified means to abstain from any further surgery, and such an eye can be considered lost. In monocular patients such a decision is very hard if not impossible to make. The corneal surgeon will always try to persuade his retinal counterpart to postpone a keratoplasty until the silicone oil can be safely removed from the eye at the time of grafting. From the above experiences with this new indication for keratoplasty we are being increasingly reluctant to perform a graft for silicone induced changes in patients with $20 / 40$ or better vision in the other eye unless we are convinced that the chances for visual improvement are very good and the silicone oil can safely be removed from the eye.

\section{References}

1 Cibis A, Becker B, Okun E, Canaan S. The use of liquid silicone in retinal detachment surgery. Arch Ophthalmol 1962; 68: $590-9$. 
2 Armaly MF. Ocular tolerance to silicones. Arch Ophthalmol 1962; 68: 390-5.

3 Levine AM, Ellis RA. Intraocular liquid silicone implants. Am J Ophthalmol 1963; 55: 939-42.

4 Martola EL, Dohlman CH. Silicone oil in the anterior chamber of the eye. Acta. Ophthalmol (Kbh) 1963; 41: 75-9.

5 Levenson DS, Stocker FW, Giorgiade NG. Intracorneal silicone fluid. Arch Ophthalmol 1965; 73: 90-3.

6 Liesenhoff $\mathrm{H}$, Schmitt J. Komplikationen durch flüssiges Silikon in der Vorderkammer. Ber Dtsch Ophthalmol Ges 1969; 69: 643-4.

7 Reim M, Schütte E, Cattepoel H. Experimentelle Variation der Spiegel einiger Metabolite in der Cornea. Ber Dtsch Ophthalmol Ges 1971; 71: 84-7.

8 Watzke RC. Silicone retinopiesis for retinal detachment. Arch Ophthalmol 1967; 77: 185-96.

9 Cockerham WD, Schepens CL, Freeman HM. Silicone injection in retinal detachment. Arch Ophthalmol 1970; 83: 704-12.

10 Blodi FC. Injection and impregnation of liquid silicone into ocular tissues. Am J Ophthalmol 1971; 71: 1044-51.

11 Sugar HS, Okamura ID. Ocular findings six years after silicone injection. Arch Ophthalmol 1976; 94: 612-5.

12 Manschot WA. Intravitreal silicone injection. Adv Ophthalmol 1978; 36: 197-207.

13 Leaver PK, Grey HB, Garner A. Silicone injection in the treatment of massive preretinal retraction. II. Late complications in 93 eyes. Br J Ophthalmol 1979; 63: 361-7.

14 Haut J, Chermet M, Van Effenterre G, Robert P. Techniques et résultats de l'injection de silicone liquide combinée à la vitrectomie dans le traitement des inversions rétiniennes. Bull Soc Ophtalmol France 1980; 80: 517-8.

15 Haut, J, Ullern M, Chermet M, Van Effenterre G. Complications des injections intra-oculaires de silicone. Bull Soc Ophtalmol Fr 1980; 80: 519-23.

16 Haut J, Ullern M, Chermet M, Van Effenterre G. Complications of intraocular injections of silicone combined with vitrectomy. Ophthalmologica 1980; 180: 29-35.

17 Gonvers $\mathbf{M}$. Temporary use of intraocular silicone oil in the treatment of detachment with massive periretinal proliferation. Ophthalmologica 1982; 184: 210-8.

18 Scott JD. A rationale for the use of liquid silicone. Trans Ophthalmol Soc UK 1977; 97: 235-7.

19 Živojnović R. Mertens DAE, Peperkamp E. Das flüssige Silikon in der Amotiochirurgie (II). Bericht über 280 Fälle, weitere Entwicklung der Technik. Klin Monatsbl Augenheilkd 1982; 181: 444-52.

20 Landers MB, Foulks GN, Landers DM. Temporary keratoprosthesis for use during pars plana vitrectomy. Am J Ophthalmol 1981; 91: 615-9.

21 Constable I, Mohamed S, Tan PL. Super viscous silicone liquid in retinal surgery. Aust J Ophthalmol 1982; 10: 5-11.

22 Pouliquen Y, Haye C, Bisson J, Offret G. Ultrastructure de la kératopathie en bandelette. Arch Ophtalmol (Paris) 1967; 27: 149-58.

23 O'Connor GR. Calcific band keratopathy. Trans Am Ophthalmol Soc 1972; 70: 58-81.

24 Waring GO, Bourne WM, Edelhauser HF, Kenyon KR. The corneal endothelium. Normal and pathologic structure and function. Ophthalmology 1982; 89: 531-90. 